This item was submitted to Loughborough's Research Repository by the author.

Items in Figshare are protected by copyright, with all rights reserved, unless otherwise indicated.

\title{
Nitrogen deposition and prey nitrogen uptake control the nutrition of the carnivorous plant Drosera rotundifolia
}

\section{PLEASE CITE THE PUBLISHED VERSION}

http://dx.doi.org/10.1016/j.scitotenv.2015.01.067

\section{PUBLISHER}

(C) Elsevier B.V

\section{VERSION}

AM (Accepted Manuscript)

\section{PUBLISHER STATEMENT}

This work is made available according to the conditions of the Creative Commons Attribution-NonCommercialNoDerivatives 4.0 International (CC BY-NC-ND 4.0) licence. Full details of this licence are available at: https://creativecommons.org/licenses/by-nc-nd/4.0/

\section{LICENCE}

CC BY-NC-ND 4.0

\section{REPOSITORY RECORD}

Millett, Jonathan, G.W. Foot, and B.M. Svensson. 2015. "Nitrogen Deposition and Prey Nitrogen Uptake Control the Nutrition of the Carnivorous Plant Drosera Rotundifolia". Loughborough University. https://hdl.handle.net/2134/17472. 


\title{
Nitrogen deposition and prey nitrogen uptake control the nutrition of the carnivorous plant Drosera rotundifolia
}

\author{
Millett J. ${ }^{1 *}$, Foot G.W. ${ }^{1}$, Svensson B.M. ${ }^{2}$ \\ ${ }^{1}$ Centre for Hydrological and Ecosystem Science, Department of Geography, Loughborough \\ University, Loughborough, LE11 3TU, UK. \\ ${ }^{2}$ Department of Plant Ecology and Evolution, Uppsala University, Norbyvägen 18 D, SE-752 \\ 36, Uppsala, Sweden
}

*Corresponding author: j.millett@lboro.ac.uk 


\section{Abstract}

Nitrogen (N) deposition has important negative impacts on natural and semi-natural ecosystems, impacting on biotic interactions across trophic levels. Low-nutrient systems are particularly sensitive to changes in $\mathrm{N}$ inputs and are therefore more vulnerable to $\mathrm{N}$ deposition. Carnivorous plants are often part of these ecosystems partly because of the additional nutrients obtained from prey. We studied the impact of $\mathrm{N}$ deposition on the nutrition of the carnivorous plant Drosera rotundifolia growing on 16 ombrotrophic bogs across Europe. We measured tissue N, phosphorus $(\mathrm{P})$ and potassium $(\mathrm{K})$ concentrations and prey and root $\mathrm{N}$ uptake using a natural abundance stable isotope approach. Our aim was to test the impact of $\mathrm{N}$ deposition on $D$. rotundifolia prey and root $\mathrm{N}$ uptake, and nutrient stoichiometry. Drosera rotundifolia root $\mathrm{N}$ uptake was strongly affected by $\mathrm{N}$ deposition, possibly resulting in reduced $\mathrm{N}$ limitation. The contribution of prey $\mathrm{N}$ to the $\mathrm{N}$ contained in $D$. rotundifolia ranged from 20 to $60 \%$. $\mathrm{N}$ deposition reduced the maximum amount of $\mathrm{N}$ derived from prey, but this varied below this maximum. Drosera rotundifolia tissue N concentrations were a product of both root N availability and prey $\mathrm{N}$ uptake. Increased prey $\mathrm{N}$ uptake was correlated with increased tissue $\mathrm{P}$ concentrations indicating uptake of $\mathrm{P}$ from prey. $\mathrm{N}$ deposition therefore reduced the strength of a carnivorous plant-prey interaction, resulting in a reduction in nutrient transfer between trophic levels. We suggest that $\mathrm{N}$ deposition has a negative impact on $D$. rotundifolia and that responses to $\mathrm{N}$ deposition might be strongly site specific.

Key words: atmospheric nitrogen deposition; carnivorous plants; Drosera rotundifolia; plantinsect interactions; round-leaved sundew; stable isotopes 


\section{Introduction}

Atmospheric nitrogen (N) deposition is a globally important pollutant (Galloway et al. 2008; Bobbink et al. 2010), which has significant local and regional impacts on ecosystems (Bobbink et al. 2010). $\mathrm{N}$ deposition increases $\mathrm{N}$ availability which can have direct impacts on individual plants (Tomassen et al. 2003; van Heerwaarden et al. 2003) and can also impact species interactions across trophic levels (Tylianakis et al. 2008). Understanding these impacts is crucial because they can result in altered species abundance, plant community composition (Payne et al. 2013) and reduced biodiversity (Stevens et al. 2004). Ombrotrophic (rain fed) bogs are nutrient poor and obtain their entire $\mathrm{N}$ budget from deposition, making them particularly sensitive to N deposition (Bobbink et al. 1998; Lovett et al. 2009). Carnivorous plants are typical of ombrotrophic bogs (Givnish et al. 1984) which makes them sensitive to changes in nutrient availability, for example through the effects of increased atmospheric $\mathrm{N}$ deposition (Ellison and Gotelli 2002).

Carnivorous plants supplement nutrients obtained through root uptake by capturing, digesting and assimilating the nutrients in animal prey, usually arthropods (Juniper et al. 1989). The uptake of prey nutrients uncouples growth and reproduction from root nutrient availability and enables carnivorous plants to successfully compete with non-carnivorous plants (Karlsson et al. 1996) when $\mathrm{N}$ availability is low. The value of the captured prey is dependent on root nutrient availability; responses to prey addition are normally reduced or absent in more nutrient replete plants (Ellison 2006). Carnivorous plants can also forage for prey, reducing investment in prey capture when the value of that prey is reduced (Ellison and Gotelli 2002; Thorén et al. 2003). It is therefore predicted that prey-derived nutrients become a less important component of their nutrition as root nutrient availability increases; but there is limited evidence to support this basic assumption. This is important because the ecological and evolutionary advantage of carnivory 
should be related to the degree to which prey-derived nutrients replace root-derived nutrients. Furthermore, while carnivorous plant growth is generally limited by $\mathrm{N}$ availability (Ellison and Gotelli 2001), captured prey contains N, P, K, Ca while atmospheric deposition is mostly N.

Experimental approaches have provided significant insight into carnivorous plant nutrition and the effects of atmospheric nitrogen deposition (e.g. see Ellison 2006). There is, however, a need to investigate carnivorous plant nutrition in situ and with no experimental manipulation, to avoid experimental artefacts. Many studies add prey to traps and measure plant responses (see Ellison, 2006 for a review of these studies); however, that the plant was not catching that number of prey may itself be significant. Similarly root N additions, e.g., Svensson (1995), are often unrealistic, being less frequent, more regular and at higher concentrations than atmospheric deposition in situ. To our knowledge only one study (Millett et al. 2012b) has provided any in situ evidence of decreased reliance on prey-derived nutrients when root nutrient availability is increased. The interpretation of this relatively small study is, however, limited due to the potential confounding of temperature and precipitation along the latitudinal $\mathrm{N}$ deposition gradient studied. In the present non-manipulative study we investigated $D$. rotundifolia growing in situ at 16 sites across Europe. We measured tissue N, P and K content and the relative contributions of root $v$ s prey $\mathrm{N}$ using a natural abundance stable isotope ratio $\left(\delta^{15} \mathrm{~N}\right)$ method (Schulze et al. 1991). We predicted that:

1. Drosera rotundifolia $\mathrm{N}$ content would be a product of root $\mathrm{N}$ availability (i.e., rates of $\mathrm{N}$ deposition) and prey $\mathrm{N}$ uptake and will be unaffected by temperature or precipitation; 2. prey $\mathrm{N}$ uptake and the contribution of prey $\mathrm{N}$ to the $\mathrm{N}$ content of $D$. rotundifolia would decrease with increasing $\mathrm{N}$ deposition across the entire range of $\mathrm{N}$ deposition; and 
3. tissue concentrations of other nutrients would be unchanged by $\mathrm{N}$ uptake (root and prey), but nutrient stoichiometry would reflect decreasing $\mathrm{N}$ limitation due to increased (root and prey) $\mathrm{N}$ uptake.

\section{Materials and methods}

\subsection{Study sites}

Where present we collected Drosera rotundifolia plants ( $n=10$ per hummock), Sphagnum capitula (i.e., c. $10 \mathrm{~cm}^{2}$ of the top $0.5 \mathrm{~cm}$ of the plant) and potential arthropod prey from Sphagnum spp. hummocks ( $n=6-10$ hummocks per site, depending on bog area) at 13 ombrotrophic bogs across Europe (details of sampling in SEM1; site details in Fig. A1 and Table A1). These bogs covered a wide geographic range (latitude: $47.2^{\circ}-68.3^{\circ} \mathrm{N}$, longitude: $5.7^{\circ} \mathrm{W}-$ $\left.19.6^{\circ} \mathrm{E}\right)$ and a wide range of $\mathrm{N}$ deposition levels $\left(0.05-2.70 \mathrm{~g} \mathrm{~m}^{-2}\right.$ year $\left.{ }^{-1}\right)$.

The $\delta^{15} \mathrm{~N}$ of all tissues and nitrogen $(\mathrm{N})$ of $D$. rotundifolia tissues was analysed at all sites and phosphorus $(\mathrm{P})$ and potassium $(\mathrm{K})$ content of $D$. rotundifolia tissue were measured at 11 sites (excluding the UK sites) (for details of analytical procedure see SEM1).

For each site, modelled mean annual $\mathrm{N}$ deposition, summer temperature (MST) and precipitation (PP) data for the previous five years up to the sampling date were calculated (see SEM1 for details of data sets). A five-year mean was used to represent the likely time scale of impacts on D. rotundifolia which has an average life span of 6 years (Crowder et al. 1990), while balancing the likely larger influence of more recent abiotic conditions.

\subsection{Data analysis}

The relative contributions of root- and prey-derived $\mathrm{N}$ to the total $\mathrm{N}$ content of the plants were determined by utilising the discrimination of ${ }^{15} \mathrm{~N}$ that occurs between trophic levels 
(Peterson and Fry 1987; Post 2002). The contribution of insect-derived N to the total $\mathrm{N}$ content of $D$. rotundifolia was calculated using a simple one-isotope, two-source, end-member mixing model as follows:

$\% \mathrm{~N}_{\mathrm{dfp}}=\left[\left(\delta^{15} \mathrm{~N}_{\text {DROSERA }}-\delta^{15} \mathrm{~N}_{\text {SPHAGNUM }}\right) /\left(\delta^{15} \mathrm{~N}_{\text {INSECT }}-\delta^{15} \mathrm{~N}_{\text {SPHAGNUM }}\right)\right] \times 100(1)$

where $\% \mathrm{~N}_{\mathrm{dfp}}$ is the percentage of $\mathrm{N}$ derived from insect prey, $\delta^{15} \mathrm{~N}_{\text {DROSERA }}$ is the $\delta^{15} \mathrm{~N}$ of the pooled sample of $D$. rotundifolia plants, $\delta^{15} \mathrm{~N}_{\text {SPHAGNum }}$ is the $\delta^{15} \mathrm{~N}$ of the capitula of the Sphagnum sp. in which D. rotundifolia is growing, and $\delta^{15} \mathrm{~N}_{\text {INSECT }}$ is the $\delta^{15} \mathrm{~N}$ of the sampled insects available as prey.

The data from these sites were combined with the three sites in Millett et al. (2012b) who used an identical sampling protocol. Drosera rotundifolia dry mass, $\% \mathrm{~N}$ and $\% \mathrm{~N}_{\mathrm{dfp}}$ were used to calculate the following variables: total $\mathrm{N}$ per plant, total prey-derived $\mathrm{N}$ per plant $\left(\mathrm{N}_{\mathrm{dfp}}\right)$ and total root-derived $\mathrm{N}$ per plant $\left(\mathrm{N}_{\mathrm{dfr}}\right)$. $\mathrm{N}_{\mathrm{dfp}}$ and $\mathrm{N}_{\text {dfr }}$ were also calculated on a per unit of total plant dry mass basis.

The influence of $\mathrm{N}$ deposition, $\mathrm{PP}, \mathrm{MST}$ and where appropriate $\mathrm{N}_{\mathrm{dfp}} /$ mass on the measured plant characteristics were analysed using multiple linear regression in IBM SPSS Statistics 20.0 (IBM Corp. 2011). Where only one predictor was significant the 'curve fitting' function in IBM SPSS Statistics was used to determine the model with best fit for the appropriate bi-variate relationship (based on the model with the highest $\mathrm{r}^{2}$ ). For $\% \mathrm{~N}_{\mathrm{dfp}}$ and $\mathrm{N}_{\mathrm{dfp}}$ quantile regression was used to estimate the regression slopes and intercepts of the 25th, 50th and 75th percentiles.

\section{Results}

Drosera rotundifolia plants were present at all sites except for Ringinglow Bog (UK5). MST and PP were not significant predictors for any of the measured or derived variables (See Table A2 for results of multiple linear regressions). There was a clear linear relationship between 
the rate of atmospheric $\mathrm{N}$ deposition and Sphagnum tissue $\mathrm{N}$ concentrations and the total amount of $\mathrm{N}$ contained in D. rotundifolia plants (Fig. 1a, 1b; linear regression: Sphagnum N concentration $-\mathrm{F}_{1,14}=34.2, P<0.001, \mathrm{r}^{2}=0.071 ; D$. rotundifolia total $\mathrm{N}$ content $-\mathrm{F}_{1,13}=20.9, P$ $=0.001, \mathrm{r}^{2}=0.63$ ). There was no impact of $\mathrm{N}$ deposition on $D$. rotundifolia mass (Table A2), but tissue $\mathrm{N}$ concentration increased with $\mathrm{N}$ deposition (Fig. 3) indicating that changes in total $\mathrm{N}$ content are due to increasing tissue $\mathrm{N}$ concentrations rather than increasing size. There were also clear relationships between modelled $\mathrm{N}$ deposition and the total amount of root-derived $\mathrm{N}$ in $D$. rotundifolia plants (Fig. 1c; regression: $\mathrm{F}_{1,13}=35.7, P<0.001, \mathrm{r}^{2}=0.73$, respectively).

At every site the mean $\delta^{15} \mathrm{~N}$ of $D$. rotundifolia tissue was between that of Sphagnum and potential prey. $\delta^{15} \mathrm{~N}$ of $D$. rotundifolia decreased in response to increasing $\mathrm{N}$ deposition (Fig. 2a; linear regression: $\mathrm{F}_{1,13}=9.9, P=0.008, \mathrm{r}^{2}=0.43$ ), but no significant relationship existed between $\mathrm{N}$ deposition and the $\delta^{15} \mathrm{~N}$ of Sphagnum or the collected potential prey items. There was a clear, statistically significant nonlinear relationship between $\mathrm{N}$ deposition and $D$. rotundifolia prey-N content. Specifically the regression line plotting the 75th percentile of the data was negatively related both to $\mathrm{N}$ deposition for $\mathrm{N}_{\mathrm{dfp}}$ expressed as a proportion of total $\mathrm{N}$ content (Fig. 2b) and as a proportion of plant dry mass (Fig. 2c). The slope of the regression line was statistically significant for the former (Quantile regression: slope $=-0.163, P=0.007$ ) and showed a clear negative trend for the latter (Quantile regression: slope $=-2.22, P=0.057$ ). However, for the 50th and 25th percentiles there was no significant relationship between $\mathrm{N}$ deposition and prey-N content (Quantile regression: $\% \mathrm{~N}_{\text {dfp }}$ : 50th - slope $=-0.150, P=0.087$; 25 th - slope $=-0.045, P=0.462 ; \mathrm{N}_{\text {dfp }}: 50$ th - slope $=-1.77, P=0.320 ; 25$ th - slope $=0.371, P$ $=0.726)$. 
Drosera rotundifolia tissue N concentration was on average 1.09\% (range: $0.62-1.42 \%$ ) and was a product of both $\mathrm{N}$ deposition (i.e., root availability) and prey-N uptake (Fig. 3), showing a positive relationship with both. Drosera rotundifolia tissue P concentration was on average $0.11 \%$ (range: $0.09-0.16 \%$ ) and did not change significantly with $\mathrm{N}$ deposition (Table A2) but did increase as the prey- $\mathrm{N}$ content of $D$. rotundifolia increased (Fig. 4; linear regression: $\mathrm{F}_{1,9}=16.2, P=0.003, \mathrm{r}^{2}=0.64$ ). No such relationship existed for tissue $\mathrm{K}$ concentrations (Table A2), which were on average $0.57 \%$ (range: $0.48-0.71 \%$ ). Increasing $\mathrm{N}$ deposition was significantly related to increasing $D$. rotundifolia tissue N:P ratios, which were on average 9.11 (range: 6.06-12.38; Table A2, Fig. 5; linear regression: $\mathrm{F}_{1,9}=14.9, P=0.004, \mathrm{r}^{2}=0.62$ ), but not $\mathrm{N}: \mathrm{K}$ (average: 1.77; range: 1.16-2.40) and P:K ratios (average: 0.20; range: 0.16-0.29). However, tissue prey-N content did not impact on tissue nutrient stoichiometry.

\section{Discussion}

Laboratory studies and in-situ experimental studies of carnivorous plant nutrition have shown that prey $\mathrm{N}$ is less valuable for nutrient replete plants (Ellison 2006). We provide good evidence that prey $\mathrm{N}$ is a less important component of the nutrition of $D$. rotundifolia when root $\mathrm{N}$ availability increases: the contribution of prey $\mathrm{N}$ to the $\mathrm{N}$ content of Drosera rotundifolia decreases with increasing $\mathrm{N}$ deposition. $\delta^{15} \mathrm{~N}$ of $D$. rotundifolia tissue was strongly negatively related to the amount of modelled $\mathrm{N}$ deposition received by a bog. This is the trend that would be expected if they were incorporating less (relatively ${ }^{15} \mathrm{~N}$ enriched) prey $\mathrm{N}$ into their tissues (Peterson and Fry 1987; Post 2002; Brearley 2011). This pattern was not seen with Sphagnum spp. or with a sample of potential prey from each site, suggesting that it is not due to differences in the $\delta^{15} \mathrm{~N}$ of precipitation or any other site specific factors. We combined the $\delta^{15} \mathrm{~N}$ of $D$. rotundifolia, Sphagnum and potential prey in a simple one-isotope, two-source, end-member 
mixing model to quantify the contribution of prey- and root-derived $\mathrm{N}$ to the total $\mathrm{N}$ contained in D. rotundifolia. This approach has been used extensively for food-web studies (Schmidt et al. 2007), in plants for quantifying $\mathrm{N}_{2}$ fixation (Shearer and Kohl 1986) and to quantify prey $\mathrm{N}$ uptake in carnivorous plants (Brearley 2011). The limitations of this approach have been discussed previously (Millett et al. 2012a, 2012b) with the general consensus being that this approach provides a good semi-quantitative estimate of the contribution of the two sources. It is also appreciated that the 'root' $\mathrm{N}$ uptake component might also comprise deposited $\mathrm{N}$ taken up through the leaves.

There were large differences between populations in the amount of $\mathrm{N}$ contained in the plants that was derived from prey (varying between 20.1 and 59.5\%). This is consistent with values between different carnivorous plant species (19.6-87.1\%; Ellison and Gotelli 2001). It is therefore clear that differences between sites are important for the role of prey nutrients for carnivorous plant nutrition. A large amount of this variability can be attributed to differences in the amount of $\mathrm{N}$ deposition received by the bogs. Our data, however, suggest that this is not a simple linear response. The maximum amount of $\mathrm{N}$ from prey is determined by $\mathrm{N}$ deposition, but the contribution can vary below that maximum, independently of $\mathrm{N}$ deposition. This suggests that root $\mathrm{N}$ availability (i.e., $\mathrm{N}$ deposition) is a major control over prey- $\mathrm{N}$ uptake as has been previously suggested (Millett et al. 2003, 2012a, 2012b), but that other factors also have important impacts on prey- $\mathrm{N}$ uptake. These factors are particularly important when $\mathrm{N}$ deposition is low, becoming less important with increasing $\mathrm{N}$ deposition.

In the bogs in our study the scale of differences in the amounts of prey $\mathrm{N}$ in $\mathrm{D}$. rotundifolia tissues is large. For sites receiving relatively low inputs of atmospheric $\mathrm{N}$ deposition, the concentration of prey-N in $D$. rotundifolia tissues varied four-fold. We found no evidence that 
meteorological differences were responsible; precipitation and summer temperature had no impact on any measured variables. We can therefore only speculate on the reasons for differences between populations. These may, for example, be due to differences between sites in: prey availability (Zamora 1995); competition with spiders for prey (Jennings et al. 2010); or kleptoparasitism (Thum 1989). Future work should focus on determining which, if any of these, is the reason for these differences in prey- $\mathrm{N}$ uptake.

The physiological mechanisms for $\mathrm{N}$ controls over the differences in prey- $\mathrm{N}$ uptake were not measured. Increasing $\mathrm{N}$ deposition was strongly related to root- $\mathrm{N}$ uptake potentially 'diluting' the prey- $\mathrm{N}$ in the plant and so altering the contribution of each. The evidence, however, in this study also suggests that the plants were able to reduce prey-N uptake as the total concentration in plant tissues decreased with increasing $\mathrm{N}$ deposition (rather than only the amount of prey-N relative to the amount of root-N). Gaining nutrients from prey involves four distinct steps: prey attraction (though this is not necessarily essential), capture, digestion and nutrient uptake (Joel et al. 1985; Adlassnig et al. 2010). It might be changes in any or a number of these mechanisms that result in the observed differences in prey capture. There is no evidence as yet that $D$. rotundifolia actually attracts prey (Foot et al. 2014); but investment in prey capture (through the production of sticky mucilage) is reduced when root $\mathrm{N}$ availability is increased experimentally (Thorén et al. 2003), which might be the mechanism here. Such a reduction in investment in prey capture has not been demonstrated in-situ for $D$. rotundifolia but has been shown for Sarracenia purpurea by Ellison and Gotelli (2002). Changes in other parts of the process should, however, not be discounted; the production of digestive enzymes, for example, also carries a metabolic cost and so the plants might reduce enzyme production, thus reducing rates or efficiency of prey digestion. 
We predicted that tissue concentrations of nutrients other than $\mathrm{N}$ would be unchanged by $\mathrm{N}$ uptake (root and prey), but nutrient stoichiometry would reflect decreasing $\mathrm{N}$ limitation due to increased (root and prey) $\mathrm{N}$ uptake. Our data confirm that plant tissue $\mathrm{N}$ concentrations were dependent on both root $\mathrm{N}$ and prey $\mathrm{N}$ uptake, but tissue $\mathrm{P}$ concentrations were also related to prey $\mathrm{N}$ uptake. This suggests that the $D$. rotundifolia plants were assimilating P from their prey as has been demonstrated previously (Karlsson and Carlsson 1984; Wakefield et al. 2005; Ellison 2006). As a result of this $P$ uptake from prey, tissue nutrient stoichiometry was affected by atmospheric deposition but not by prey $\mathrm{N}$ uptake. What does this mean for plant nutrient limitation? Nutrient limitation can be inferred from tissue nutrient concentrations and nutrient stoichiometry. Our results suggest that $D$. rotundifolia in this study were in general $\mathrm{N}$ limited and not $\mathrm{P}$ limited $(\mathrm{N}<2 \%, \mathrm{P} \geq 0.1 \%, \mathrm{~N}: \mathrm{P}<14$ as indicated by Koerselman and Meuleman 1996; Verhoeven et al. 1996; Aerts and Chapin 2000), despite having the 'option' to augment root-N uptake through prey capture. This supports the suggestion that the most important nutrient gained from prey is P (Chandler and Anderson 1976; Stewart and Nilsen 1993; Wakefield et al. 2005; Ellison 2006), and explains continued N limitation, despite prey $\mathrm{N}$ uptake. Both $\mathrm{N}$ deposition and prey $\mathrm{N}$ uptake reduced $\mathrm{N}$ limitation by increasing tissue $\mathrm{N}$ concentrations; only $\mathrm{N}$ deposition, however, altered the relative importance of $\mathrm{N} v s \mathrm{P}$ limitation. This reflects to some extent the results of experimental studies (summarised by Ellison 2006) which show that inorganic $\mathrm{N}$ results in a shift from $\mathrm{N}$ limitation towards $\mathrm{P}$ limitation and prey addition results in a shift away from P limitation and towards $\mathrm{N}$ limitation. These results differ only slightly from those found in-situ by Méndez and Karlsson (2005) who found that the nutrient stoichiometry of the carnivorous plant Pinguicula vulgaris was affected by root $\mathrm{N}$ availability but not by prey 
capture; with the lack of a prey capture effect confounded by their limited measure of prey capture.

$\mathrm{K}$ limitation is indicated by tissue $\mathrm{K}$ concentrations $<0.8 \%$ and $\mathrm{N}: \mathrm{K}$ ratio $>3.1$ or $\mathrm{P}: \mathrm{K}$ ratio $>0.29$ (Olde Venterink et al. 2002). Tissue K concentrations < 0.8\% indicate K limitation in all D. rotundifolia populations, but $\mathrm{N}: \mathrm{K}$ and $\mathrm{P}: \mathrm{K}$ ratios were above those indicating $\mathrm{K}$ limitation (3.1 and 0.29 respectively), suggesting that the low tissue concentration might be a result of low tissue nutrient concentrations in carnivorous plants in general rather than a specific limitation of K. These differences in tissue nutrient concentrations and nutrient stoichiometry suggest that prey $\mathrm{N}$ uptake is not necessarily comparable to root $\mathrm{N}$ uptake because of the additional nutrients gained from prey. As a result, the reduction in prey nutrient uptake in response to atmospheric $\mathrm{N}$ deposition might result in nutrient imbalances in the plants.

Our results indicate that, with respect to the key process of prey $\mathrm{N}$ uptake, the response to $\mathrm{N}$ deposition may differ for plants growing at different bogs. Those which grow on low $\mathrm{N}$ deposition bogs and gain a high proportion of their $\mathrm{N}$ from prey, might be affected to a greater extent than those (also growing on low $\mathrm{N}$ deposition sites) for which prey $\mathrm{N}$ represents a relatively small proportion of their $\mathrm{N}$ nutrition. For these plants carnivory currently provides less apparent advantage (in terms of additional $\mathrm{N}$ ), placing them at greater threat because they might lack the flexibility to respond to increased $\mathrm{N}$ deposition. So the impact on prey $\mathrm{N}$ uptake might be smaller, but the impact on the plant or the population might be larger than at sites where the plants on average obtain more $\mathrm{N}$ from prey. Conversely, those which currently gain a large amount of $\mathrm{N}$ from prey potentially have more flexibility to direct resources away from prey capture. Interestingly the bog which received the highest level of modelled $\mathrm{N}$ deposition (Ringinglow Bog) contained no D. rotundifolia. This is despite reported previous presence 
(Conway 1947, 1949) an abundance of appropriate habitat and a long search. The species has a downward trend (BRC and BSBI 2014). Could it be that D. rotundifolia is unable to persist in these relatively high $\mathrm{N}$ conditions? Nitrogen fertilization has been shown to reduce Sphagnum growth (after an initial stimulus of growth; Gunnarsson and Rydin 2000). This may affect cooccurring low-growing vascular plant species negatively (such as the carnivorous Drosera species) as they rely on Sphagnum for support. However, along a Swedish gradient from nitrogen-poor to nitrogen-rich bog ecosystems (stretching from the north to the south-west (Wiedermann et al. 2009) D. rotundifolia seems to increase in areas with high nitrogen deposition (Flodin and Gunnarson 2008). Conversely, a negative impact of N on D. rotundifolia has been demonstrated; the population size was reduced within one year when the $\mathrm{N}$ deposition rate was artificially increased from 10 to $20 \mathrm{~kg} \mathrm{~N} \mathrm{ha}^{-1} \mathrm{year}^{-1}$ (Redbo-Torstensson 1994). Our suggestion is that as Sphagnum incremental growth decreases, incoming light would increase - at least temporarily - before larger, more competitive vascular plants increase in abundance. In this temporal window, resources gained by catching prey could be used by carnivorous plants for reproduction. This alternative is not possible for other low-statured vascular plants, which thus get outcompeted. We therefore hypothesize that the physiological changes shown in our study are indicators of a negative impact of $\mathrm{N}$ deposition on $D$. rotundifolia which ultimately results in local extinction, as has been demonstrated for other carnivorous plant species (Gotelli and Ellison 2002).

\subsection{Conclusions}

We conclude that the differences between populations in the nutrition of the $D$. rotundifolia plants in our study are driven primarily by $\mathrm{N}$ deposition, but that other factors are important at low $\mathrm{N}$ deposition levels. Global environmental change impacts on biotic 
interactions, which might affect the stability of ecosystems (Tylianakis et al. 2008). Atmospheric nitrogen deposition is a key driver of global environmental change and has been shown to affect biotic interactions such as plant-pollinator, plant-fungal and plant-herbivore interactions (Tylianakis et al. 2008). We have shown that $\mathrm{N}$ deposition reduces the strength of a carnivorous plant-prey interaction, resulting in a reduction in nutrient transfer between trophic levels. The consequence of this on the carnivorous plant and the whole community is not clear, but that there is a significant change is in itself important. Further research is required to explore the impact of these pollution-driven changes on $D$. rotundifolia biochemistry, interactions with other plants and with the arthropod community (i.e., prey) on the bogs. In particular, further understanding is required of how prey availability varies between bogs and how this variability in prey abundance affects prey capture and plant fitness. In addition, future research should focus on how $\mathrm{N}$ deposition affects interactions between carnivorous plants and other plant species and how $\mathrm{P}$ uptake from prey affects our interpretation of carnivorous plant ecology and evolution.

\section{Acknowledgements}

We would like to thank the national statutory bodies, site managers and site owners for allowing access and facilitating this study. JM received funding from the British Ecological Society (BES) and the Botanical Research Fund, GF received funding from the UK Engineering and Physical Sciences Research Council in the form of a summer undergraduate research bursary and from the BES, and BMS from the Department of Ecology and Genetics, Uppsala University. We acknowledge the E-OBS dataset from the EU-FP6 project ENSEMBLES (http://ensembleseu.metoffice.com) and the data providers in the ECA\&D project (http://www.ecad.eu). The manuscript greatly benefited from comments of two anonymous reviewers. 


\section{References}

Adlassnig W, Lendl T, Peroutka M, Lang I. Deadly Glue-Adhesive Traps of Carnivorous Plants. In: Byern J, Grunwald I, editors. Biol Adhes Syst. Vienna: Springer; 2010. p. 15-28.

Aerts R, Chapin F. The mineral nutrition of wild plants revisited: a re-evaluation of processes and patterns. Adv Ecol Res. 2000;30:1-67.

Bobbink R, Hicks K, Galloway J, Spranger T, Alkemade R, Ashmore M, et al. Global assessment of nitrogen deposition effects on terrestrial plant diversity: a synthesis. Ecol Appl. 2010;20:30-59.

Bobbink R, Hornung M, Roelofs J. The effects of air-borne nitrogen pollutants on species diversity in natural and semi-natural European vegetation. J Ecol. 1998;86:717-38. http://dx.doi.org/10.1046/j.1365-2745.1998.8650717.x

BRC, BSBI. Online atlas of the Bristish and Irish Flora. [Internet]. 2014 [cited 2014 Apr 9]. Available from: http://www.brc.ac.uk/plantatlas/index.php?q=plant/drosera-rotundifolia

Brearley FQ. Natural abundance of stable isotopes reveals the diersity of carnivorous plant diets. Carniv Plant Newsl J Int Carniv Plant Soc. 2011;40(3):84-7.

Chandler GE, Anderson JW. Studies on the nutrition and growth of Drosera species with reference to the carnivorous habit. New Phytol. 1976;76:129-41.

Conway V. Ringinglow Bog, near Sheffield: part II. The present surface. J Ecol. 1949;37(1):148-70.

Conway VM. Ringinglow Bog, near Sheffield: part I. Historical. J Ecol. 1947;34(1):149-81.

Crowder A, Pearson M, Grubs P, Hanglois P. Biological flora of the British Isles: Drosera L. J Ecol. 1990;78:233-67.

Ellison AM. Nutrient limitation and stoichiometry of carnivorous plants. Plant Biol. 2006;8(6):740-7.

Ellison AM, Gotelli NJ. Evolutionary ecology of carnivorous plants. Trends Ecol Evol. 2001;16(11):623-9.

Ellison AM, Gotelli NJ. Nitrogen availability alters the expression of carnivory in the northern pitcher plant, Sarracenia purpurea. Proc Natl Acad Sci U S A. 2002;99(7):4409-12.

Flodin LÅ, Gunnarson U. Vegetationsförändringar på mossar och kärr i Halland. Sven Bot Tidskr. 2008;102:177-87. 
Foot G, Rice SP, Millett J. Red trap colour of the carnivorous plant Drosera rotundifolia does not serve a prey attraction or camouflage function. Biol Lett. 2014;10:20131024. http://dx.doi.org/10.1098/rsbl.2013.1024

Galloway JN, Townsend AR, Erisman JW, Bekunda M, Cai Z, Freney JR, et al. Transformation of the nitrogen cycle: recent trends, questions, and potential solutions. Science. 2008 May;320(5878):889-92.

Givnish TJ, Burkhardt EL, Happel RE, Weintraub JD. Carnivory in the bromeliad Brocchinia reducta, with a cost/benefit model for the general restriction of carnivorous plants to sunny, moist, nutrient-poor habitats. Am Nat. 1984;124(4):479-97.

Gotelli NJ, Ellison AM. Nitrogen deposition and extinction risk in the Northern Pitcher Plant, Sarracenia purpurea. Ecology. 2002 Oct;83(10):2758.

Gunnarsson U, Rydin H. Nitrogen fertilisation reduces Sphagnum production in bog communities. New Phytol. 2000;147:527-37.

Van Heerwaarden LM, Toet S, Aerts R. Nitrogen and phosphorus resorption efficiency and proficiency in six sub-arctic bog species after 4 years of nitrogen fertilization. J Ecol 2003;91(6):1060-70. http://doi.wiley.com/10.1046/j.1365-2745.2003.00828.x

IBM Corp. IBM SPSS Statistics for Windows. Armonk, NY: IBM Corp.; 2011.

Jennings DE, Krupa JJ, Raffel TR, Rohr JR. Evidence for competition between carnivorous plants and spiders. Proc Biol Sci. 2010 7;277(1696):3001-8.

Joel D, Juniper B, Dafni A. Ultraviolet patterns in the traps of carnivorous plants. New Phytol. 1985;101(4):585-93.

Juniper BBE, Robins RJ, Joel DM. The Carnivorous Plants. Academic Press; 1989.

Karlsson PS, Carlsson B. Why does Pinguicula vulgaris L. trap insects? New Phytol. 1984;97:25-30.

Karlsson PS, Svensson BM, Carlsson BÅ. The significance of carnivory for three Pinguicula species in a subarctic environment. Ecol Bull. 1996;45:115-20.

Koerselman W, Meuleman AFM. The vegetation N:P ratio: a new tool to detect the nature of nutrientlLimitation. J Appl Ecol. 1996;33(6):1441-50.

Lovett GM, Tear TH, Evers DC, Findlay SEG, Cosby BJ, Dunscomb JK, et al. Effects of air pollution on ecosystems and biological diversity in the eastern United States. Ann N Y Acad Sci. 2009;1162:99-135. 
Méndez M, Karlsson PS. Nutrient stoichiometre in Pinguicula vulgaris: nutrient availabilti, plant size, and reproductive status. Ecology. 2005;86(4):982-91.

Millett J, Jones RI, Waldron S. The contribution of insect prey to the total nitrogen content of sundews (Drosera spp.) determined in situ by stable isotope analysis. New Phytol. 2003;158(3):527-34. http://dx.doi.org/10.1046/j.1469-8137.2003.00763.x

Millett J, Leith ID, Sheppard LJ, Newton J. Response of Sphagnum papillosum and Drosera rotundifolia to reduced and oxidized wet nitrogen deposition. Folia Geobot. 2012 a Feb 24;47(2):179-91.

Millett J, Svensson BM, Newton J, Rydin H. Reliance on prey-derived nitrogen by the carnivorous plant Drosera rotundifolia decreases with increasing nitrogen deposition. New Phytol. 2012 b;195(1):182-8. http://dx.doi.org/ 10.1111/j.1469-8137.2012.04139.x

Olde Venterink H, Wassen M, Verkroost A, De Ruiter P. N, P, and K budgets along nutrient availability and productivity gradients in wetlands. Ecol Appl. 2002;12:1010-26.

Payne RJ, Dise NB, Stevens CJ, Gowing DJ. Impact of nitrogen deposition at the species level. Proc Natl Acad Sci U S A. 2013;110(3):984-7.

Peterson BJ, Fry B. Stable isotopes in ecosystem studies. Annu Rev Ecol Syst. 1987 a;18:293320.

Post DM. Using stable isotopes to estimate trophic position: models, methods, and assumptions. Ecology. 2002;83:703-18.

Schmidt SN, Olden JD, Solomon CT, Vander Zanden MJ. Quantitative approaches to the analysis of stable isotope food web data. Ecology. 2007;88(11):2793-802.

Schulze E-D, Gebauer G, Schulze W, Pate JS. The utilisation of nitrogen from insect capture by different growth forms of Drosera from southwest Australia. Oecologia. 1991;87:240-6.

Shearer GB, Kohl DH. N 2 - fixation in feld settings: estimations based on natural ${ }^{15} \mathrm{~N}$ abundance. Aust J Plant Physiol. 1986;13:699-756.

Stevens CJ, Dise NB, Mountford JO, Gowing DJ. Impact of nitrogen deposition on the species richness of grasslands. Science. 2004;303(5665):1876-9.

Stewart CN, Nilsen ET. Responses of Drosera capensis and D. binata var. multifida (Droseraceae) to manipulations of insect availability and soil nutrient levels. New Zeal J Bot. 1993;31:385-90.

Svensson BM. Competition between Sphagnum fuscum and Drosera rotundifolia: a case of ecosystem engineering. Oikos. 1995;74:205-12. 
Thorén LM, Tuomi J, Kamarainen T, Laine K. Resource availability affects investment in carnivory in Drosera rotundifolia. New Phytol. 2003;159(2):507-11.

http://doi.wiley.com/10.1046/j.1469-8137.2003.00816.x

Thum M. The significance of opportunistic predators for the sympatric carnivorous plant species Drosera intermedia and Drosera rotundifolia. Oecologia. 1989;81:397-400.

Tomassen HBM, Smolders AJP, Lamers LPM, Roelofs JGM. Stimulated growth of Betula pubescens and Molinia caerulea on ombrotrophic bogs: role of high levels of atmospheric nitrogen deposition. J Ecol. 2003 Jun;91(3):357-70. http://doi.wiley.com/10.1046/j.13652745.2003.00771.x

Tylianakis JM, Didham RK, Bascompte J, Wardle DA. Global change and species interactions in terrestrial ecosystems. Ecol Lett. 2008;11(12):1351-63. http://blackwellsynergy.com/doi/abs/10.1111/j.1461-0248.2008.01250.x

Verhoeven JTA, Koerselman W, Mauleman AFM. Nitrogen- or phosphorus-limited growth in herbaceous, wet vegetation: relations with atmospheric inputs and management regimes. Trends Ecol Evol. 1996;11:494-7.

Wakefield AE, Gotelli NJ, Wittman SE, Ellison AM. Prey addition alters nutrient stoichiometry of the carnivorous plant Saracenia Purpurea. Ecology. 2005 Jul;86(7):1737-43. http://www.esajournals.org/doi/abs/10.1890/04-1673

Wiedermann MM, Gunnarsson U, Nilsson MB, Nordin A, Ericson L. Can small-scale experiments predict ecosystem responses? An example from peatlands. Oikos. 2009;118:449-56.

Zamora R. The trapping success of a carnivorous plant, Pinguicula vallisneriifolia: The cumulative effects of availability, attraction, retention and robbery of prey. Oikos. 1995;73(3):309-22.

\section{Figure legends}

Figure 1. Nitrogen (N) content of Drosera rotundifolia and Sphagnum growing on European bogs. Presented are: (a) Sphagnum tissue N concentrations (b) total N and (c) total N from root uptake $\left(\mathrm{N}_{\mathrm{dfr}}\right)$. Each symbol is the mean for plants taken from hummocks $(n=6-10)$ on a single bog. Error bars are 1 SEM, based on values for different hummocks. Open symbols are data from 
(Millett et al. 2012b), filled symbols are data collected for the present study. The black line is the fitted linear regression model.

Figure 2. $\delta^{15} \mathrm{~N}$ and calculated prey nitrogen $\left(\mathrm{N}_{\mathrm{dfp}}\right)$ uptake for Drosera rotundifolia growing on European bogs. Presented are: (a) D. rotundifolia (circles), prey (triangles) and Sphagnum (Squares) $\delta^{15} \mathrm{~N}$ at each bog ; (b) $\mathrm{N}_{\mathrm{dfp}}$ as a percentage of total plant nitrogen for D. rotundifolia and (c) $\mathrm{N}_{\mathrm{dfp}}$ as a per unit of $D$. rotundifolia plant dry mass. Each symbol is the mean for plants taken from hummocks ( $n=6-10)$ on a single bog. Error bars are 1 SEM, based on the values for different hummocks, where error bars are not visible they are smaller than the symbol. Open symbols are data used in (Millett et al. 2012b), filled symbols are data collected for the present study. Labels identify study sites as detailed in Fig. A1 and Table A1. The black line in (a) is the fitted linear regression model for $D$. rotundifolia and in (b) and (c) the 0.5 quantile. Dashed lines in (b) and (c) are the 0.25 (short dashes) and 0.75 (long dashes) quantiles. NS=not statistically significant $(P>0.05)$.

Figure 3. Drosera rotundifolia tissue nitrogen (N) concentrations for plants growing on European bogs. Presented are the mean values for plants from hummocks on each bog $(n=6-$ 10), the modelled $\mathrm{N}$ deposition and amount of prey derived $\mathrm{N}\left(\mathrm{N}_{\mathrm{dfp}}\right)$ per unit of plant dry mass. The plane represents the fitted equation based on analysis using multiple linear regression. The equation of the fitted plane is: Equation of fitted plane:

$\% \mathrm{~N}=0.532+(0.222 \times \mathrm{N}$ deposition $)+\left(0.086 \times{ }_{\mathrm{Ndfp}}\right)$

Figure 4. Relationship between the amount of prey derived N in the tissues of Drosera rotundifolia plants $\left(\mathrm{N}_{\mathrm{dfp}}\right)$ per unit of plant dry mass and plant tissue P percent concentration for plants growing on European bogs. Each symbol is the mean for plants taken from hummocks ( $n$ $=6-10$ ) on a single bog. Error bars are 1 SEM, based on the values for different hummocks, 
where error bars are not visible they are smaller than the symbol. The black line is the fitted linear regression model. Labels identify study sites as detailed in Fig. A1 and Table A11. Figure 5. Tissue N:P of Drosera rotundifolia plants growing on different bogs in Europe. Each symbol is the mean for plants taken from hummocks $(n=6-10)$ on a single bog. Error bars are 1 SEM, based on the values for different hummocks, where error bars are not visible they are smaller than the symbol. The black line is the fitted linear regression model. 
Figure 1
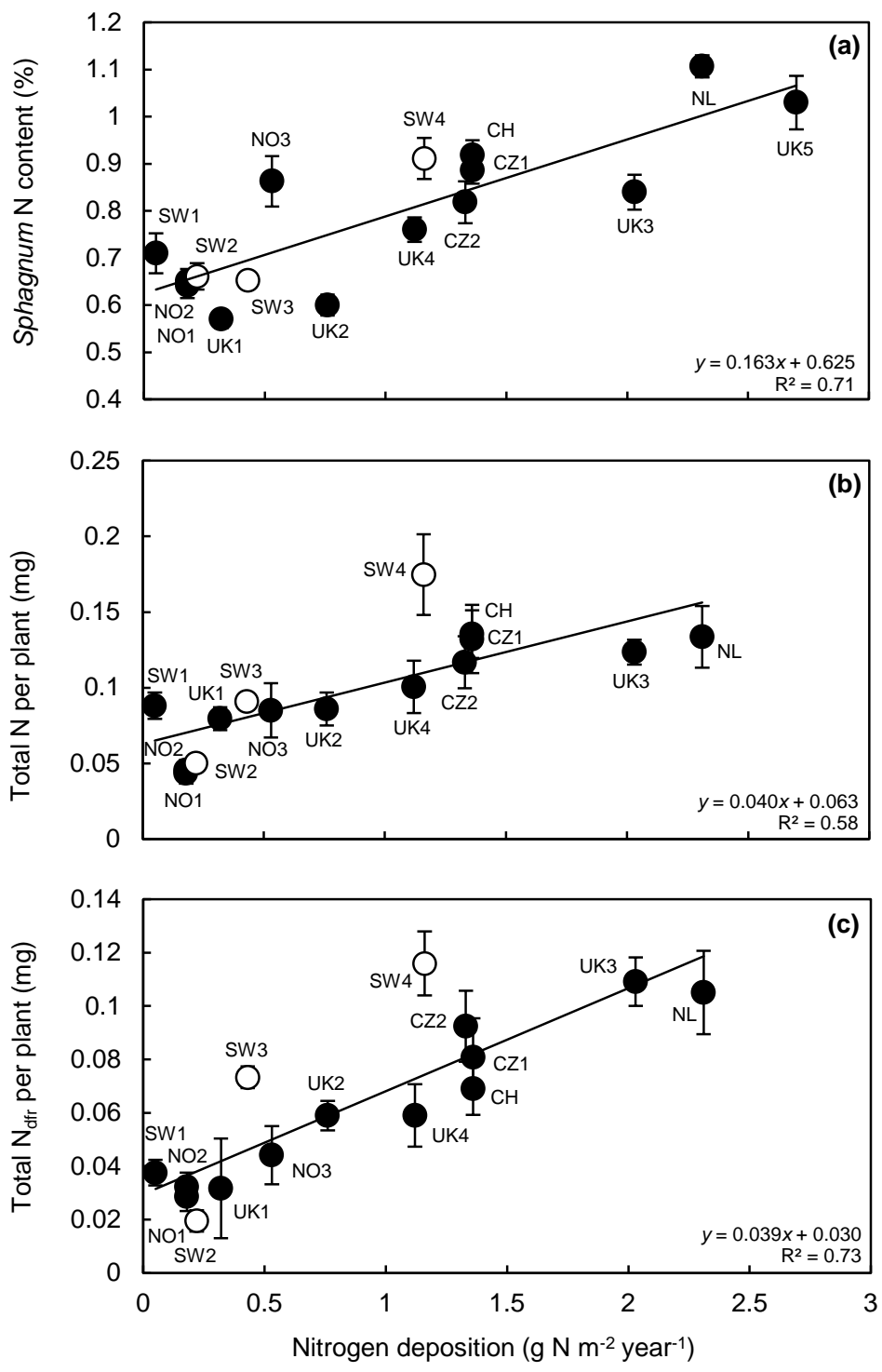
Figure 2
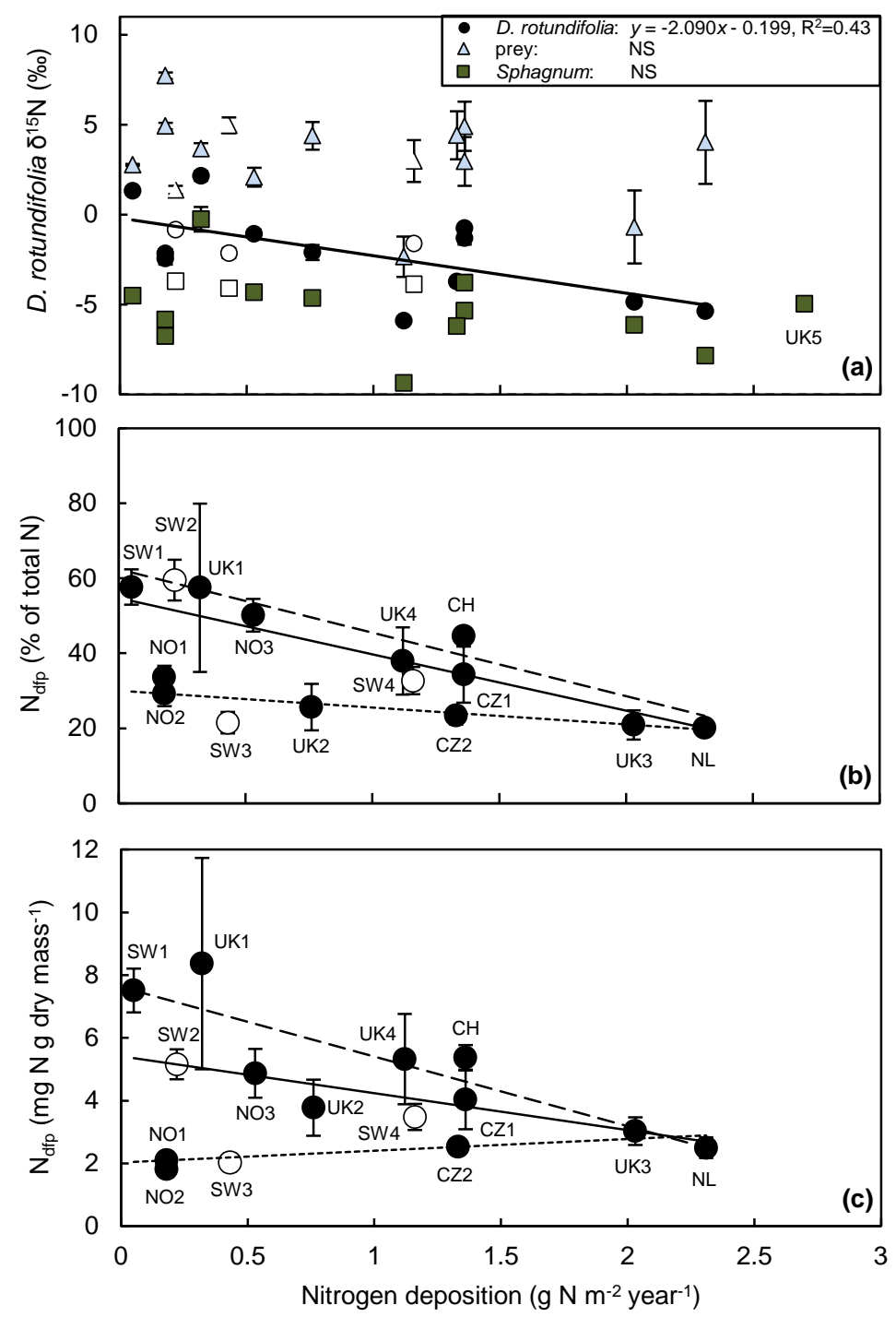
Figure 3

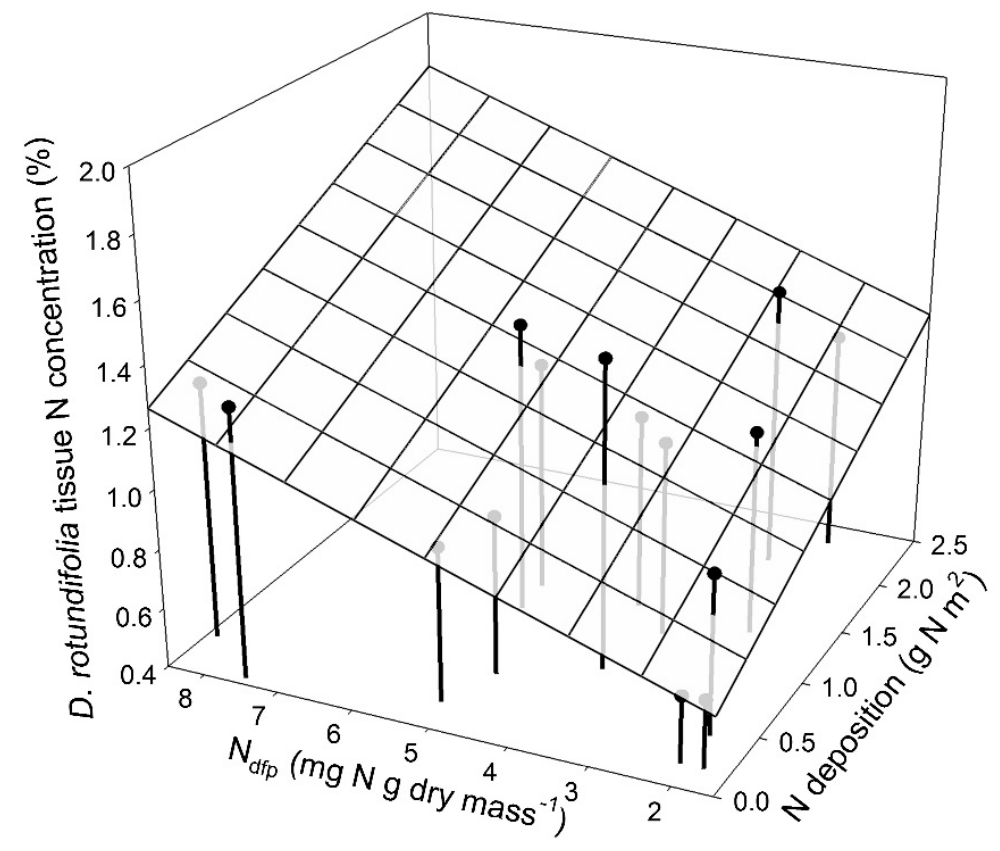


Figure 4

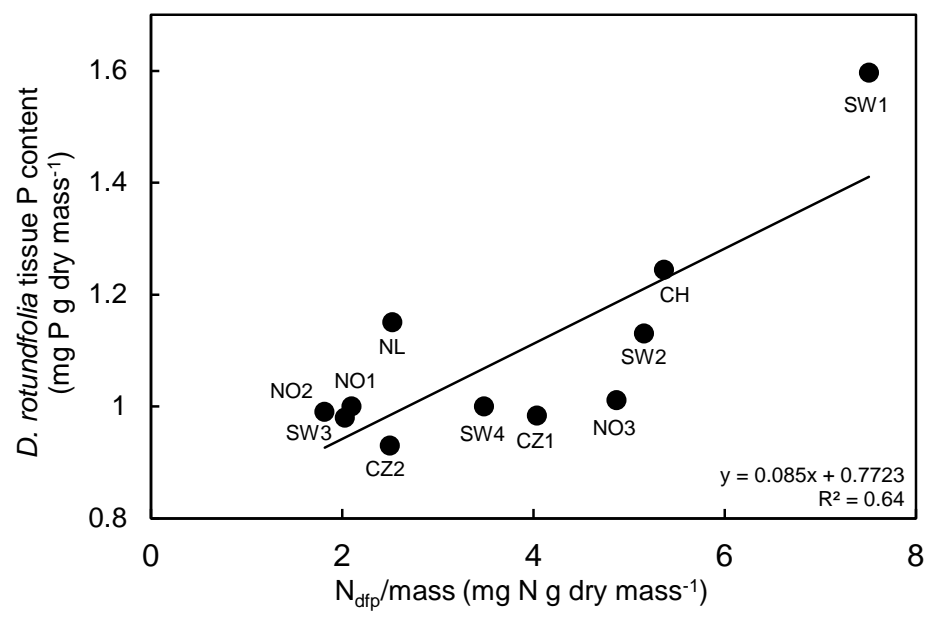


Figure 5

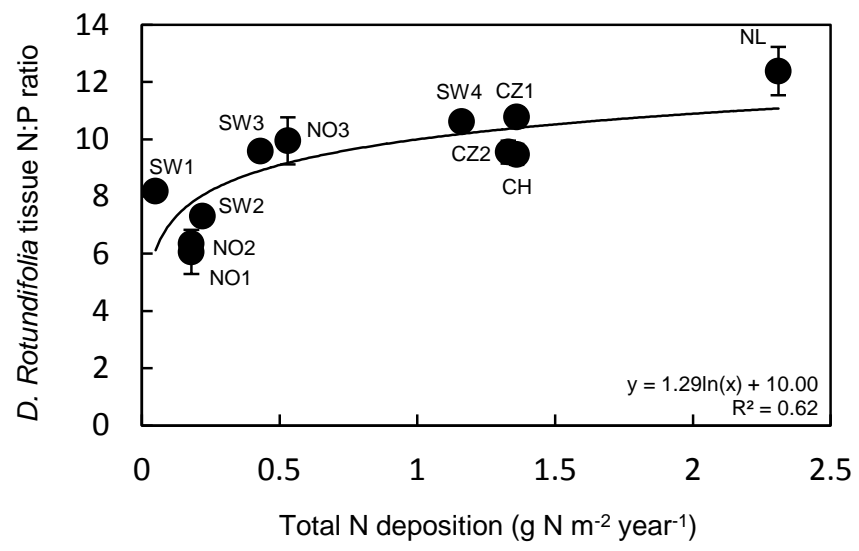




\section{Appendices}

Appendix 1: Details of sample collection procedure, plant tissue analysis, environmental variable data sets and approach to regression analysis.

Figure A1: Location of study bogs.

Table A1: Characteristics of study bogs.

Table A2: Results of multivariate linear regressions. 


\section{Appendices for: Millett J., Foot G.W., Svensson B.M. Nitrogen deposition and prey nitrogen uptake control the nutrition of the carnivorous plant Drosera rotundifolia. Science of the Total Environment}

Appendix 1: Details of sample collection procedure, plant tissue analysis, environmental variable data sets and approach to regression analysis.

\section{Sample collection}

Where present we collected Drosera rotundifolia plants from Sphagnum spp. hummocks ( $n=6-10$ hummocks per site, depending on bog area) from 13 ombrotrophic bogs across Europe (Fig. S1, Table S1). We selected these bogs to provide a wide geographic range (latitude: $47.2^{\circ}-68.3^{\circ} \mathrm{N}$, longitude: $5.7^{\circ} \mathrm{W}-19.6^{\circ} \mathrm{E}$ ) and a wide range of $\mathrm{N}$ deposition levels $\left(0.05-2.70 \mathrm{~g} \mathrm{~m}^{-2}\right.$ year $\left.^{-1}\right)$. Samples were collected in July and August over a two-year period because the amount of work involved meant that this was the only way to collect samples at similar times of the year.

Drosera rotundifolia plants ( $n=10$ per hummock) were carefully removed from each hummock and the previous years' growth was separated and discarded. A sample (three separate samples of c. $10 \mathrm{~cm}^{2}$ ) of the capitula (i.e., the top $0.5 \mathrm{~cm}$ of the plant) of the dominant Sphagnum species was collected with scissors. A sample of potential prey was collected by placing sticky yellow fly traps on the hummock for at least 24 hours and then carefully removing the captured potential prey (i.e., $<3 \mathrm{~mm}$ length) with tweezers. All samples were kept cold and transported back to a laboratory before being dried for 72 hours at $70{ }^{\circ} \mathrm{C}$; this was done within 5 days of collection. Drosera rotundifolia plants were weighed, and then all plant samples were milled to a fine powder with a ball mill (Retsch MM200). Insect samples were ground by hand to a fine powder in a small mortar.

\section{Stable isotope analysis}

either at UC Davis Stable Isotope Facility using a PDZ Europa ANCA-GSL elemental analyzer interfaced to a PDZ Europa 20-20 isotope ratio mass spectrometer (Sercon Ltd., 
Cheshire, UK) or at OEA Labs, UK, using a CE Instruments EA 1110 elemental analyser coupled to a differentially pumped Europa Scientific 2020 stable isotope ratio mass spectrometer. Results are given using the $\delta$ notation expressed in units of per mil (\%o) where $\delta^{15} \mathrm{~N}=\left[\left(\mathrm{R}_{\text {sample }} / \mathrm{R}_{\text {reference }}\right)-1\right] \times 1000$, and $\mathrm{R}={ }^{15} \mathrm{~N} /{ }^{14} \mathrm{~N}$. Data are reported with respect to the primary international reference AIR (i.e., $=0 \%$ ), and the measurements were calibrated at UC Davis using USGS-41 glutamic acid and internal standards: nylon, bovine liver, peach leaves and glutamic acid, and at OEA Labs using IAEA N1, IAEA N2 and an internal bovine liver standard. Precision for both laboratories was $0.2 \%$.

\section{Analysis of tissue Phosphorous (P) and Potassium (K)}

Plant tissue P and K were measured by AGVISE Laboratories (Northwood, ND, USA) using standard ICP spectrometry methods.

\section{Environmental variables data sets}

Annual atmospheric $\mathrm{N}$ deposition modelled using a higher resolution national model for the UK (Smith et al. 2000, NEGTAP 2001) and for non-UK sites using the lower resolution European Monitoring and Evaluation Program (EMEP)-based Integrated Deposition Model (IDEM) (Pieterse et al. 2007). Meteorological data (mean summer (June-August) temperature - MST and mean annual precipitation - PP) for the previous five years for each site (with a 0.25 degree latitude-longitude resolution) were calculated using an interpolated data set from E-OBS (Haylock et al. 2008) accessed through the KNMI climate explorer (KNMI 2013).

\section{Regression analysis approach}

The influence of the abiotic variables: $\mathrm{N}$ deposition, PP, MST and where appropriate $\mathrm{N}_{\mathrm{dfp}} /$ mass on the measured plant characteristics was analysed using multiple linear regression 
in IBM SPSS Statistics 20.0 (IBM Corp. 2011). The set of independent variables used in the model were different for different response variables. N deposition, PP and MST were used for: D. rotundifolia and Sphagnum ${ }^{15} \mathrm{~N}$ data and root- or prey-derived N. $\mathrm{N}_{\mathrm{dfp}} /$ mass was added to the model for $D$. rotundifolia mass, total $\mathrm{N}$ and $\% \mathrm{~N}$ concentration. For $\% \mathrm{P}, \% \mathrm{~K}$ and nutrient ratios a more limited model was used with only $\mathrm{N}$ deposition and prey- $\mathrm{N}$ content as the independent variables. This was to avoid over-parameterization due to the lower number of sites for these data (i.e., $n=11$ ).

\section{Quantile regression}

Initial data exploration using scatter plots for $\% \mathrm{~N}_{\mathrm{dfp}}$ and $\mathrm{N}_{\mathrm{dfp}}$ plotted against $\mathrm{N}$ deposition indicated substantial heterogeneity and a lack of normality in error distributions. Variance decreased systematically with increasing $\mathrm{N}$ deposition. These characteristics of the data indicated that quantile regression would be a more appropriate analysis (Cade and Noon 2003) as quantile regression is robust to heterogeneous variance. In addition, quantile regression enables the analysis of the upper or lower limits of a distribution rather than just the mean or median.

\section{References}

Cade, B. S., and B. R. Noon. 2003. A gentle introduction to quantile regression for ecologists. Frontiers in Ecology and Environment 1:412-420.

Haylock, M., N. Hofstra, A. Klein Tank, E. Klok, P. Jones, and M. New. 2008. A European daily high-resolution gridded dataset of surface temperature and precipitation. Journal of Geophysical Research 113.

IBM Corp. 2011. IBM SPSS Statistics for Windows. IBM Corp., Armonk, NY.

KNMI. 2013. KNMI Climate Explorer. http://climexp.knmi.nl.

NEGTAP. 2001. Regional estimation of pollutant gas dry deposition in the UK: model description, sensitivity analyses and outputs. Edinburgh. 
Pieterse, G., A. Bleeker, A. T. Vermeulen, Y. Wu, and J. W. Erismn. 2007. High resolution modelling of atmosphere-canopy exchange of acidifying and eutrophying components and carbon dioxide for European forests. Tellus 59B:412-424.

Smith, R. I., D. Fowler, M. A. Sutton, C. Flechard, and M. Coyle. 2000. Regional estimation of pollutant gas dry deposition in the UK: model description, sensitivity analyses and outputs. Atmospheric Environment 34:3757-3777. 
Table A1. Characteristics of study bogs with modelled atmospheric N deposition (for the five years prior to sampling), mean summer temperature (MST) and mean annual precipitation (PP). The location of the bogs is shown in Fig. S1.

\begin{tabular}{lccccc}
\hline \multicolumn{1}{c}{ Site } & Country & Latitude - longitude & $\begin{array}{c}\text { N deposition } \\
\left.\mathbf{( g ~ m}^{-2} \text { year }^{-1}\right)^{*}\end{array}$ & $\begin{array}{c}\mathbf{M S T}^{\dagger} \\
\left.\mathbf{(}^{\circ} \mathbf{C}\right)\end{array}$ & $\begin{array}{c}\text { PP } \\
(\mathbf{m m} \\
\text { year }^{-1)}\end{array}$ \\
\hline $\begin{array}{l}\text { Sites visited in 2010 } \\
\text { (Millett } \text { et al. 2012a) }\end{array}$ & & & & & \\
SW2: Lappmyran & Sweden & $64.16^{\circ} \mathrm{N}-19.58^{\circ} \mathrm{E}$ & 0.22 & 13.8 & 621 \\
SW3: Akerlänna Römosse & Sweden & $60.02^{\circ} \mathrm{N}-17.35^{\circ} \mathrm{E}$ & 0.43 & 16.1 & 611 \\
SW4: Saxnäs mosse & Sweden & $68.33^{\circ} \mathrm{N}-18.78^{\circ} \mathrm{E}$ & 1.16 & 15.6 & 952 \\
Sites visited in 2011 & & & & \\
CZ1: Cihadla & Czech Republic & $50.68^{\circ} \mathrm{N}-15.25^{\circ} \mathrm{E}$ & 1.36 & 17.6 & 749 \\
CZ2: Murtvy luh & Czech Republic & $48.87^{\circ} \mathrm{N}-13.88^{\circ} \mathrm{E}$ & 1.33 & 14.9 & 963 \\
NO1: Lysklettmyrin & Norway & $63.32^{\circ} \mathrm{N}-10.49^{\circ} \mathrm{E}$ & 0.18 & 13.6 & 1066 \\
NO2: Skjetnmyra & Norway & $63.32^{\circ} \mathrm{N}-9.96^{\circ} \mathrm{E}$ & 0.18 & 13.7 & 1135 \\
NO3: Bervamyr & Norway & $58.52^{\circ} \mathrm{N}-6.75^{\circ} \mathrm{E}$ & 0.53 & 12.7 & 2270 \\
CH: Etang de la Gruère & Switzerland & $47.24^{\circ} \mathrm{N}-7.04^{\circ} \mathrm{E}$ & 1.36 & 16.1 & 1105 \\
NL: 't Groote Veen & Netherlands & $52.83^{\circ} \mathrm{N}-6.45^{\circ} \mathrm{E}$ & 2.31 & 16.6 & 876 \\
Sites visited in 2012 & & & & & \\
UK1: Inverasdale Peatlands & Scotland & $57.46^{\circ} \mathrm{N}-3.61^{\circ} \mathrm{W}$ & 0.32 & 12.2 & 905 \\
UK2: Moidach More & Scotland & $57.85^{\circ} \mathrm{N}-5.73^{\circ} \mathrm{W}$ & 0.76 & 12.3 & 1486 \\
UK3: Butterburn Flow & England & $55.07^{\circ} \mathrm{N}-2.51^{\circ} \mathrm{W}$ & 2.03 & 12.9 & 1475 \\
UK4: Bowness Common & England & $54.92^{\circ} \mathrm{N}-3.27^{\circ} \mathrm{W}$ & 1.12 & 14.4 & 1168 \\
UK5: Ringinglow Bog & England & $53.35^{\circ} \mathrm{N}-1.60^{\circ} \mathrm{W}$ & 2.70 & 14.5 & 956 \\
SW1: Abisko & Sweden & $68.33^{\circ} \mathrm{N}-18.78^{\circ} \mathrm{E}$ & 0.05 & 9.7 & 471 \\
\hline
\end{tabular}

$* \mathrm{~N}$ deposition levels were obtained from modelled data from EMEP (www.emep.int) and for the UK from APIS (www.apis.ac.uk). ${ }^{\top}$ Mean Summer Temperature (MST) and Mean Annual Precipitation (PP) from E-OBS interpolated meteorological dataset (Haylock et al. 2008) accessed through the KNMI Climate Explorer (http://climexp.knmi.nl/). Data are for the five year period prior to sampling. 
Table A2. Results of multivariate linear regressions. Presented are the slope and $P$ value of each variable and the $\mathrm{R}^{2}, \mathrm{~F}$ and

$P$ values for the whole regression model. Different sets of independent variables were used for each dependent variable.

Significant $(P<0.05)$ are emboldened

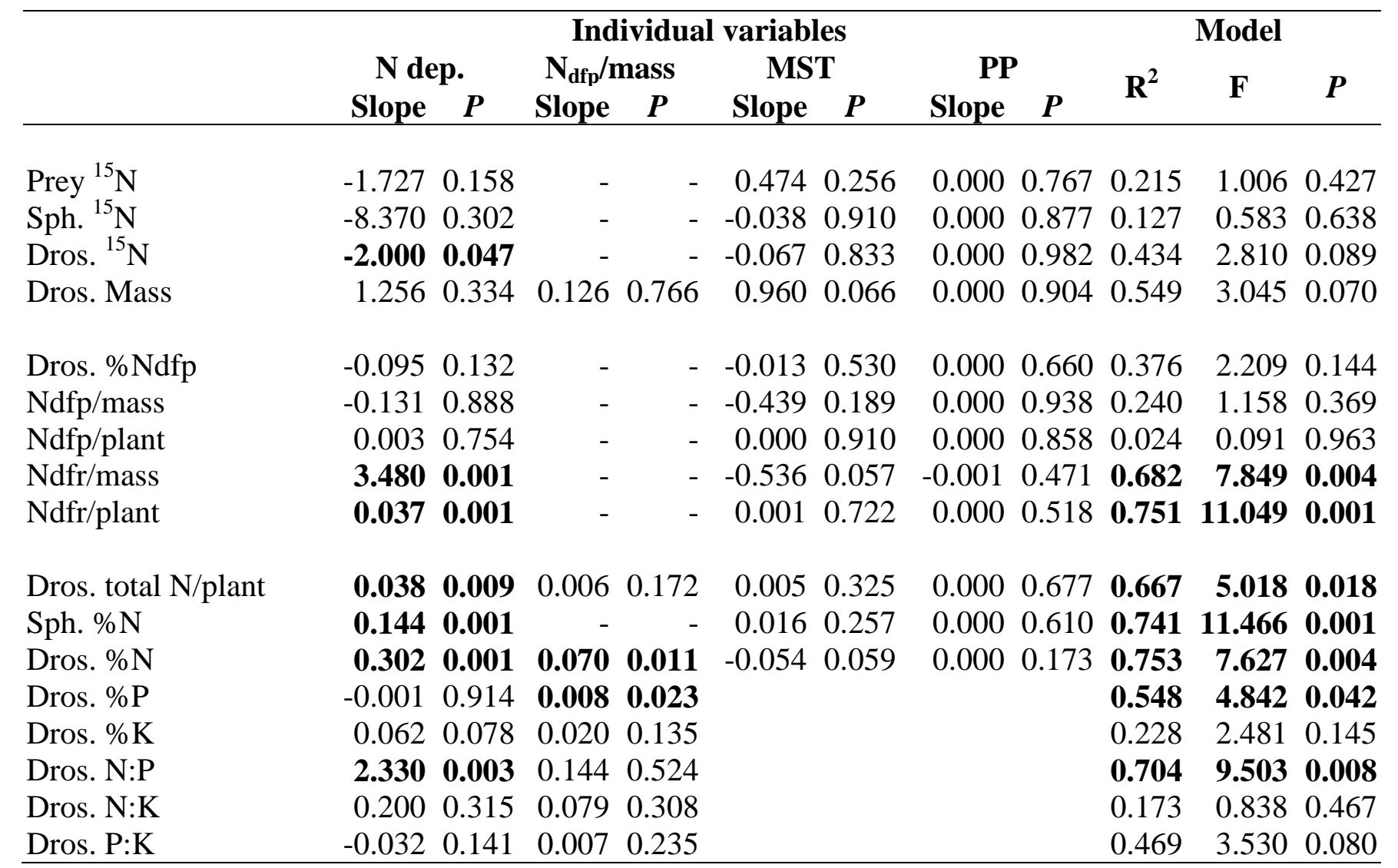

Sph.=Sphagnum, Dros. $=$ Drosera rotundifolia, $\mathrm{N}$ dep. $=$ Nitrogen deposition, $\mathrm{N}_{\mathrm{dfp}}=D$. rotundifolia $\mathrm{N}$ derived from prey, $\mathrm{N}_{\mathrm{drr}}=D$. rotundifolia $\mathrm{N}$ derived from root, MST=Mean Summer Temperature, PP=Mean Annual Precipitation. 
Figure A1. Location of study bogs. Site details are in Table 1.

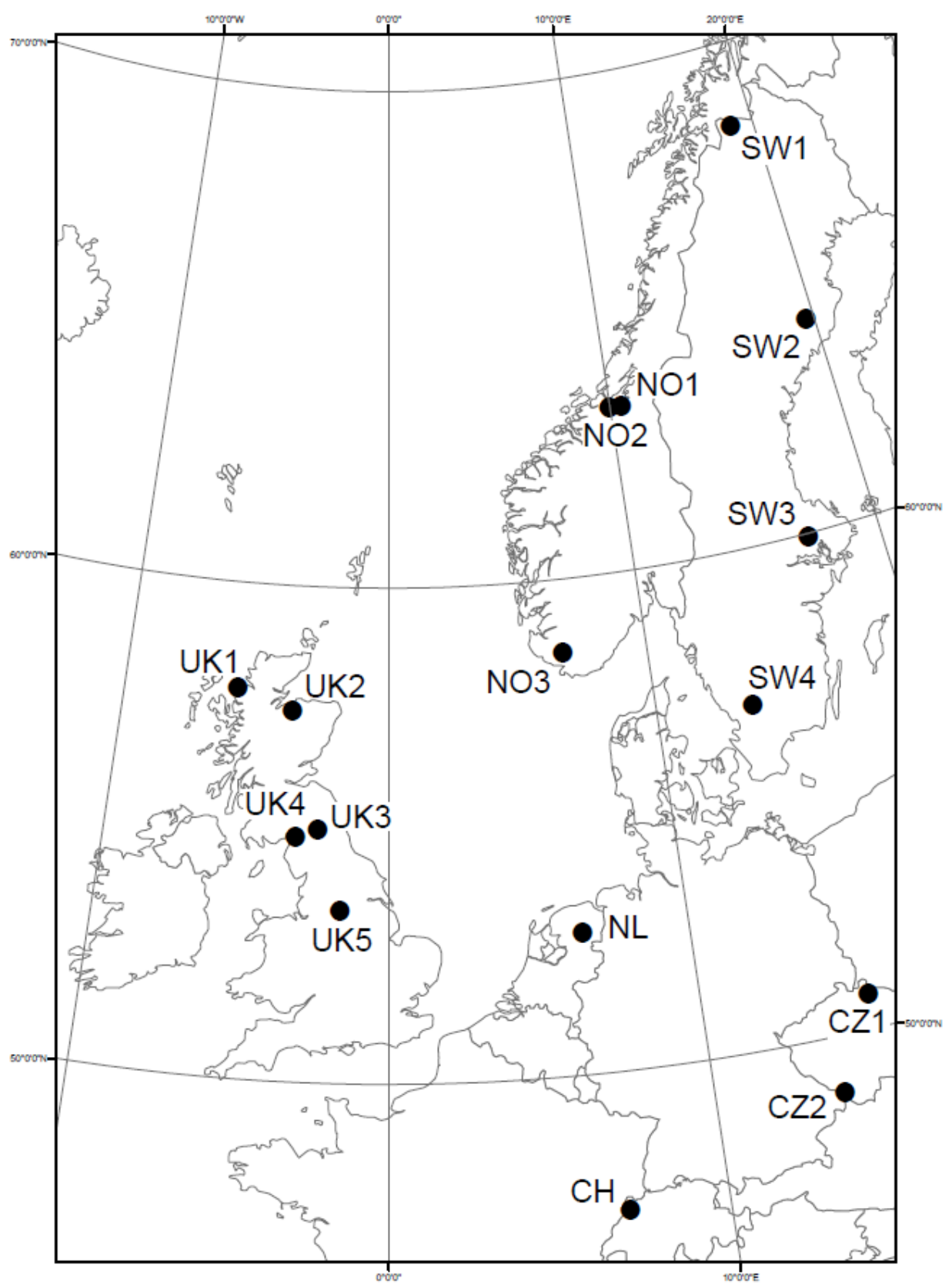

